\title{
札幌における1942・43年決定の都市計画公園に関する研究 A STUDY ON THE CITY PLANNING PARKS OF SAPPORO DECIDED IN 1942/1943
}

\author{
鈴木 依理子*，越 澤 明** \\ Eriko SUZUKI and Akira KOSHIZAWA
}

\begin{abstract}
City Planning Law was applied to Sapporo in 1923, and city planning streets, scenic zone and parks were decided in succession from 1936 to 1943 . Planning theory and characteristics of city planning parks were the following.

1) The principle of the planning parks, boulevard system and scenic zone was to realize the theory of park system and green belt

2) The layout of city planning parks was closely related to boulevard system, scenic zone and a typical green belt was uniquely planned in Sapporo.

3)The main purpose of parks was to utilize for outdoor recreation, sports and allotment.
\end{abstract}

Keywords. Sapporo, city planning park, park system, green belt, scenic zone 札幌、都市計画公園、公園緑地系統、緑地帯，風致地区

1、はじめに

1919 年（大正 8 年）都市計画法が公布され、公園は街路、河川、運 河、下水道などとともに都市計画法における都市施設の 1 つとして位 置つけられた。そして都市計画法に基き都市計画決定され、さらに事業 決定によって公園を計画的に整備していく制度手法か誕生した。その後 1940 年の法改正で都市計画施設に緑地か加わった。

都市計画法は 1920 年 1 月に東京、大阪など 6 大都市に適用され、次 いで 1923 年（大正 12 年）5月、机幌、堺、新渴、浜松、仙台、広島、 福岡など全国 25 都市に適用された注1) 1)。この 31 都市が日本で都市計 画法が早い時期から適用された主要都市である。その後、全国における 都市計画法適用の都市数は 1932 年に 104 都市に增加した注2) 2)。

当時、都市計画法が適用された都市の一般的な状況は、先ず測量と 地形図作成が行われ、都市計画区域の籁囲を定め、街路と用途地域の都 市計画決定が行われた。公園は街路、用途地域と並ふ3本柱であったが、 公園か実際に決定された都市は街路、用途地域と比べると相対的に少な

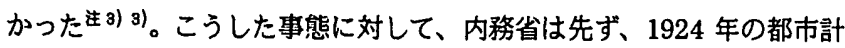
画主任官会議で各都市計画地方委員会に「公園系統計画根本調查の件」 として「統一的な公園計画を確立し」と指示し、1936 年都市計画課長 通牒「公園其の他緑地計画に関する件」を各地方長官㝖に出し、「都市 計画街路、地域は相当決定を見、……末だ公園緑地に関する決定は不充
分を免れず」と公園緑地に関する計画の推進を指示している ${ }^{3)}$ 。 1920 1945 年（都市計画法施行から敗戦までの戦前）に決定された 都市計画公園、都市計画緑地に関する全国の一般的状況については佐藤 昌の大著 4) があるが、個々の都市に関する詳細な研究は蓄樻が少ない。 当時日本が影響を受けた欧米の都市計画思想は、19 世紀後半〜20世紀 初めの公園緑地系統（パークシステム）、20 世紀前半の田園都市、地方 計画 (リージョナル・ブラニング)、緑地帯（グリーンベルト）などであ る(佐藤昌 4)、石川幹子の)。この影餐については、当時の『都市公論凡 『公園緑地』注4)に多数の論考・翻訳が揭載されていること注 6)、また 戦前の池田宏、即沼一省、武居高四郎などによる都市計画の代表的な著 書からも明かである。また 1939 年に内務省が策定した東京緑地計画は 1940 1945 年の全国各地の公園緑地の基本思想をつくった重要な計画 であるが、この東京緑地計画の解説書にはボストン、シカゴ、ロンドン、 ベルリンなどの公園緑地系統、緑地帯の計画図が収録されている注6)。 1920１945 年の日本の公園緑地に関する既往研究は、内務省は佐藤

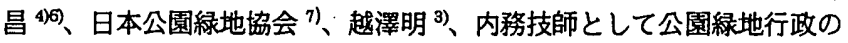

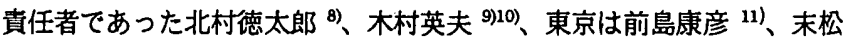

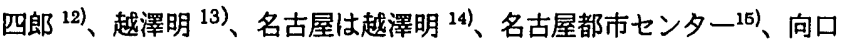
武志 ${ }^{16)}$ 、大阪は越澤明 ${ }^{17)}$ などが存在する。1940〜1945 年、日本の主 な都市で公園緑地の決定、事業が進展する。しかし『公園緑地』に東京、
* 北海道大学大学院工学研究科 大学院生

** 北海道大学大学院工学研究科 教授. 工博
Graduate Student, Graduate School of Eng., Hokkaido University Prof., Graduate School of Eng., Hokkaido University, Dr. Eng. 
大阪、名古屋、横浜、川猗に関する記述は存在するが注 7)、札幌に関す る記述は皆無であり、佐藤昌の著作 ${ }^{4)}$ にも言及がない。『机沅市史』 ${ }^{18) 、}$ 『新机幌市史』19)、『さっぽろ文庫 64 公園と緑地』20)では都市計画公 園についての概要のみが記載されている。

本研究は 1942 年、43 年に決定された札幌における最初の都市計画 公園の全体像、内容 特徵を明らかにすることを目的とする。研究の方 法としては、都市計画決定の事務を担当していた都市計画北海道地方委 員会注 8）21)、公園事業の主体である札幌市の公文貫 ${ }^{22)}$ を調查、収集、 解読し、合わせて都市研究会 ${ }^{23)}$ 、公園緑地協会 ${ }^{24)}$ 、札幌市 ${ }^{252) 26}$ の刊行 物を調査、参照した。都市計画北海道地方委員会、札幌市の公文書を使 用した都市計画公園に関する研究は本論文が最初である。

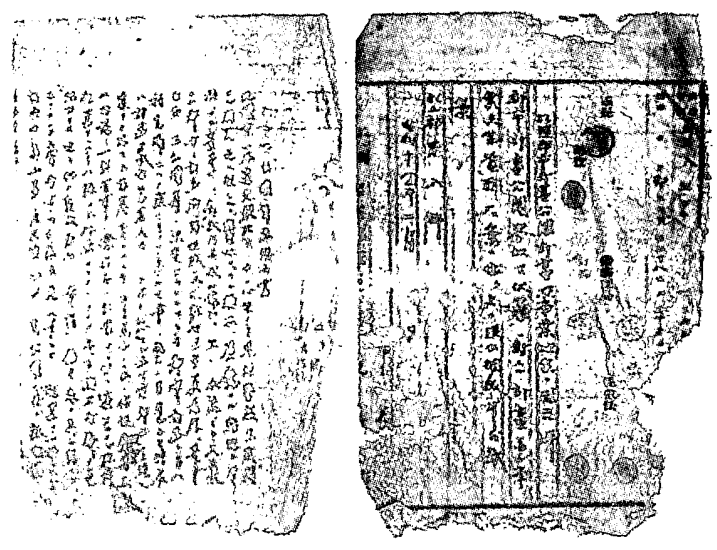

图 1 札晲市厉藏の都市計画決定图書の一部分注9) 22)

\section{2、机蛔の都市形成と都市計画の適用}

\section{2-1、明治大正期の都市形成と公園緑地}

1869 年(明治 4 年)、明治政府は北海道の政治の拠点を札幌に置き、 計画的な都市建設を開始した注 ${ }^{10)}$ 。当時の面穓は $524 \mathrm{ha、人口は} 624$ 人であったが、1899 年 (明治 32 年) 区制が実施された際、人口は 40,578 人に増加した（表 1 参照注11)）。

\section{表 1 札愰の面棈と人口の推移粈}

\begin{tabular}{|c|c|c|}
\hline 年 & 面樌 $(\mathrm{ha})$ & 스시 \\
\hline 1869 年 & 524 & 624 \\
1886 年 & 1,438 & 14,935 \\
1899 年 & 1,438 & 40,578 \\
1910 年 & 2,417 & 88,841 \\
1922 年 & 2,417 & 127,044 \\
1933 年 & 2,417 & 188,839 \\
1942 年 & 7,625 & 225,457 \\
1947 年 & 7,625 & 292,659 \\
\hline
\end{tabular}

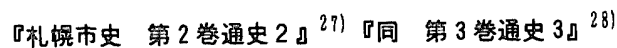
狪第 4 巻通史』 291 より作成。

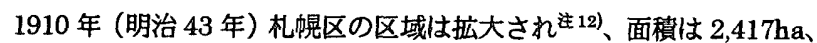
人口は 9 万人近くとなった。1922 年(大正 11 年)市制が施行され、人口 は 12 万 7 千人となり、全国 90 都市中 13 番目の都市に成長していた。 こうして机幌は北海道の中心都市として順調に成長を続けたが、大正期 は新たな公園緑地は確保されず、市街化が進行した。当時の主な公園緑 地は、防火帯としての大通道摆地注 13)、博覧会会場にも使用され賑わい
を見せていた中島公園注 14)、札幌神社境内の自然地況を生かした円山公 園这 1の)であり、何れも明治期の遺産であった注 ${ }^{16)}$ 。またその位置は市 街地中心から南・西側に偏っていた注17。

\section{2-2、都市計画法の景用と都市計画区域}

1923 年（大正 12 年）、札幌に都市計画法が適用さ机、翌 1924 年か ら都市計画区域設定のための調査が開始された。1927 年（昭和 2 年） に決定した札幌都市計画区域は、将来人口を 50 万人と予測し、1 時間 以内に市の中心地点へ到達できる範囲、すなわち大通と停車場通（現在 の駅前通り）の交差点を基点とする半径 4 マイル（約 $6.4 \mathrm{~km}$ ）の区域 内、約 $10,440 \mathrm{ha}$ であった注 ${ }^{18)}$ 。その区域には邚外の豊平町、白石村、 札幌村、琴似村、藻岩村の一部も含まれていた。

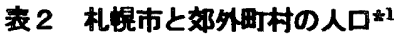

\begin{tabular}{|c|c|c|}
\hline & 1922 年(人) & 1942 年(人) \\
\hline 札幌市 & 127,044 & 225,457 \\
\hline \hline 札幌村 & 7,062 & $5,154^{ \pm 2}$ \\
\hline 白石村 & 6,371 & 10,783 \\
\hline 豊平町 & 11,284 & 21,703 \\
\hline 琴似村 & 6,344 & 11,739 \\
\hline 4 町村計 & 31,061 & 49,379 \\
\hline \hline 総 計 & 158,105 & 274,836 \\
\hline
\end{tabular}

*1『札㼛市史 第 4 巻通史 $4 \rrbracket^{291} 166$ 項より作成。 *2 1934 年 (昭和 9 年) 札䭪村の一部が札㹸市に編入され、 札帨村の人口は 10,213 人から 4,139人と減少した。

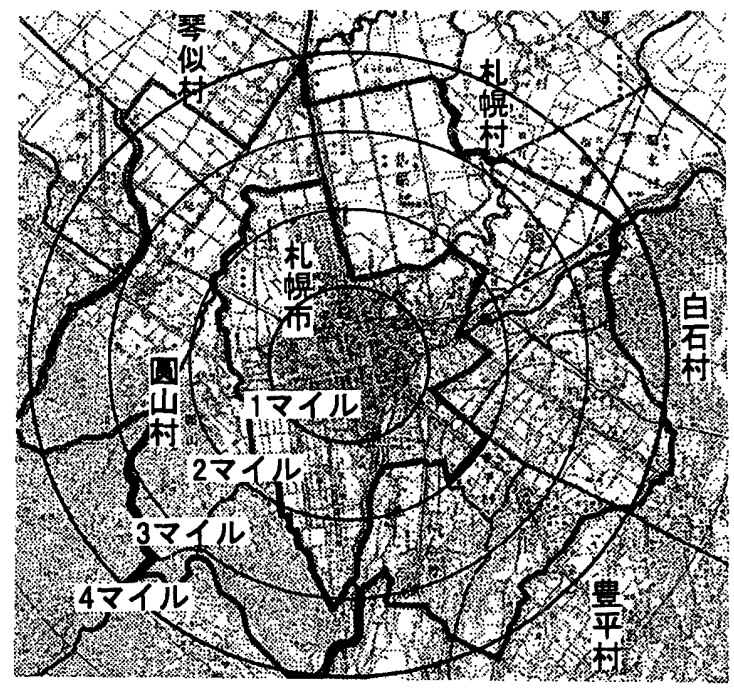

\section{图 21927 年決定机摆帮市計画区域圆}

『札蜆都市計画区域設定参考資料』 ${ }^{33}$ ）(縮尺 $1: 50000$ ）に篻者 がマイル数と地名を加篻。(決定区域は 4 マイル以内の区域）

\section{2-3 都市計画街路と風致地区}

札幌では都市計画区域の決定後、1945 年（昭和 20 年）にかけて次 のような都市計画が決定されている 252061往 19）。

1933 年 8 月 用途地域 (4 種類)

1936 年 9 月 都市計画街路（60 路線）

1939 年 7 月 風致地区 (14 地区)

1942 年 5 月 都市計画公園 (3 公園)

1943 年 5 月 都市計画公園 (2 公園)

1944 年 8 月 土地区画整理（東札幌） 
街路、風致地区についてその決定の考え方を公文書（理由書、図面、

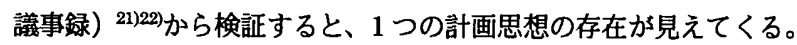
札幌の都市計画街路の特改は、将来の都市発展を見越して、まだ市街 化が始まっていない奶外地（農耕地、樹林地、低湿地）に対し、幅貝 55 $\sim 110 \mathrm{~m}$ の広幅員街路（広路）を放射・環状に 7 路線配置して都市計画 街路網の骨格をなしていることである。4 路線には都市河川を取り込み、 断面の過半はオープンスペース（植栽帯と水面）であった。また、やち だも公園通、新川公園通、伏籠公園通という名称からも公園道路（パー クウェイ、ブールヴァール）注200)として計画されていたことが判明す る ${ }^{36)}$

札幌の風致地区の特徵は、市街地の南・西部を取り囲む丘陵・山岳 地带に加えて、上記の広幅員街路や河川沿いを細長い路線型風致地区に 指定し、全市的な放射環状のパークシステム（公園緑地系統）とグリー ンベルト（緑地帯）を形成している点にある ${ }^{24) 25) 。 ~}$

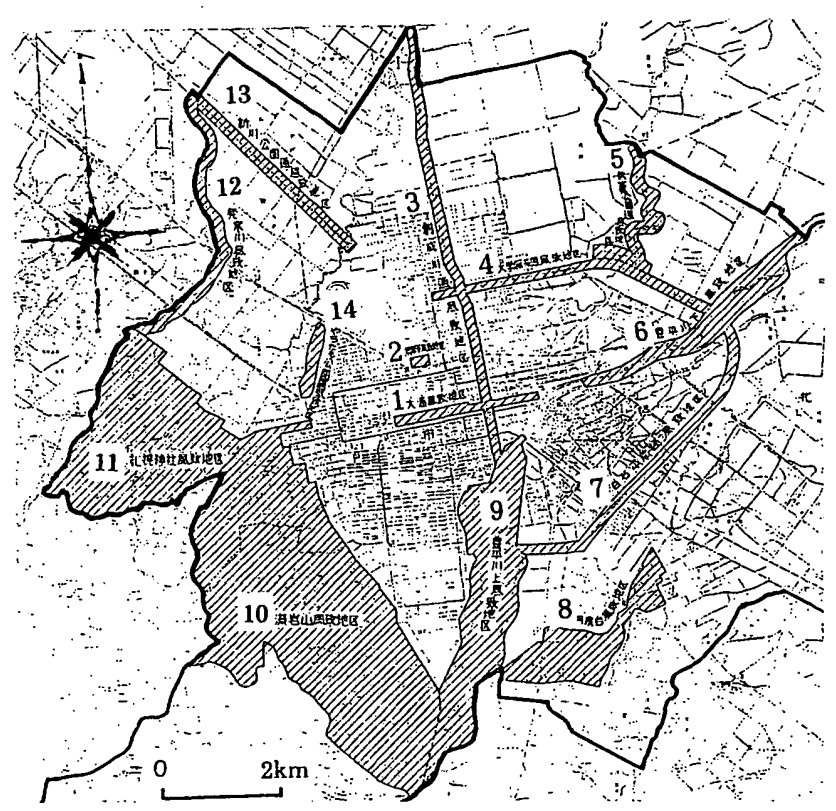

\begin{tabular}{|c|c|c|c|c|c|}
\hline N & 風致地区 & 面皘 (ha) & № & 風致地区 & 面積（ha） \\
\hline & 大通風致地区 & 33.39 & & 月寒台風致地区 & 184.9 \\
\hline & 清華亭風致地区 & 4.36 & & 帮平川上風致地区 & 388.42 \\
\hline & 㓣成川通風致地区 & 85.19 & & 莫岩山風致地区 & 1000.4 \\
\hline 4 & 大學雁来通風致地区 & 51.20 & 11 & 札媞神社風致地区 & 775.41 \\
\hline & 伏䈬公園通風致地区 & 59.22 & 12 & 発寒川風致地区 & 58.17 \\
\hline 6 & 曹平川下風致地区 & 141.70 & & 新川公園通風致地区 & 44.18 \\
\hline & 自石平岸通風致地区 & 63.67 & 14 & やちたもも公園通風致地 & 19.05 \\
\hline
\end{tabular}

图 3 札愰市風致地区图（1939 年決定） 原図は縮尺 $1: 50000$ 。图中の番号と方位、スケールは篻者が記入。 また下表も篻者作成による。それ以外は原図のままである。

都市計画決定の理由書には次のように広路のもつ保健、美観、防災の 機能に加えて、将来の都市計画公園の連鎖に言及した注目すべき記述が 存在する ${ }^{22) 。}$

「今後の都市施設として緑地帯の存置は、独り市民の保健及び都市の 美観上必要なるのみならず、偶々、火災其の他の災禍の突発に際しては これら施設にまつべきも大なるものを以て、現在、市内及び近郊に点在 せる公園及び自然緑地と連槃をとり、且、将来の都市計画公園の連鎖た らしむるべく、広路及び緑樹帯を考虑したる幹線街路を配したり。」
（傍点は引用者による、以下同様）

また風致地区決定の理由書には次のような記述がある ${ }^{22) 。 ~}$

「豊平川、創成川、発寒川、伏籠川等と共に流水沿岸何れも独特の景趣 を有す。……やちたも公園通、大学雁来通、白石平岸通等は何れも樹林 蜿蜓、環状の変帯は市街地を抱擁し、前記各所と共に、市民の保健孯楽 上、密接なる関係にあり、依って、これらを風致地区に指定し、以て市 街地の発展に伴う風致景勝の毀損を防止し、併せて、その保育を図らむ とする。」

以上より札幌においては都市計画街路、風致地区、都市計画公園が 1 つの計画思想 (パークシステム、グリーンベルト思想) のもとに計画さ れていたことが判明し、これは札幌都市計画の大きな特徵である ${ }^{36 。}$ またこうした特徵は、当時の内務省の都市計画思想の反映であり、同時 期に東京、大阪、名古屋、横浜などで決定された都市計画緑地の考え方・ 配置とも共通性が存在する。

しかしこれらの大都市の都市計画（街路、風致地区、公園、緑地など） と札幌を比較すると、札幌には次のような特色、相違点が存在している。 (1)広路 (広幅員街路) は他都市では少なく、都心に限定され（東京では 行幸道路、昭和通り、大阪では御堂筋、名古屋と横浜はなし)、パーク システムを構成していない。一方、札幌では広路が全市的なパークシス テム、グリーンベルトの構成要素となっている。また広路、風致地区、 公園の決定が連動しているのは札幌のみである。なお同時期の台湾节渵 州では広幅員街路が全市的なパークシステムやグリーンベルトの一部を 構成している都市が存在する（台北、新高港、新京、大東港など） ${ }^{34) 。 ~}$ (2)札幌では広路（広幅員街路）の沿道を風致地区とし、相乗作用で緑地 帯としているが、このような計画は机幌のみである。なお広路より幅員 が狭い並木道で風致地区が決定された事例として東京の表参道・裹参道 があるが、全市的なパークシステムではない。

(3)風致地区を広路、並木道、河川、公園などと連動して全市的な放射環 状のグリーンベルトとなるよう当初から都市計画決定している点は札幌 の特徵である。

1930 年代・40 年代の全国各地の風致地区を検証すると、京都 ${ }^{37) 、}$ 鎌倉、北九州など 5 市では風致地区は全市的な環状グリーンベルトとな っているが、風致地区の単独決定である。また、西宮では風致地区が六

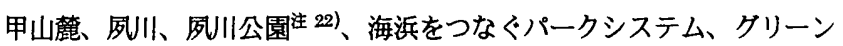
ベルトとなるよう決定されているが、広路は決定されていない。また 名古屋では 1939 年当初決定の風致地区は高級市街地の形成を目的とし ており、緑地はその外側に決定されささらに緑地を包含して風致地区が 1942 年追加決定されており、風致地区指定の趣旨が变化している ${ }^{15)}$ 。

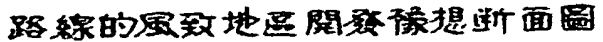

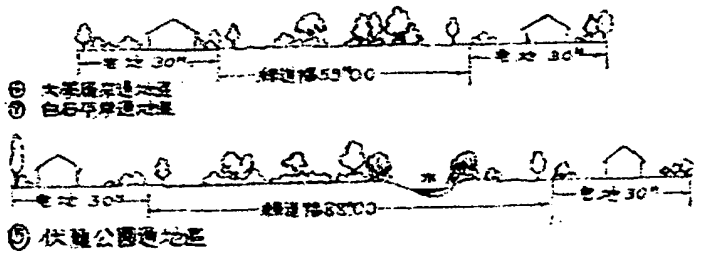

图4 路線的風致地区開発予想断面图 ${ }^{24)}$

上は大学倠来通風致地区と白石平岸通風致地区の設計予想断面。

下は代籠公園通風致地区の設計予想断面である。 
以上のような特色を有する公園緑地計画が札幌で実践された背䍗とし ては、(1)札幌は明治期の都市建設により、既成市街地のインフラ整備が 終了して方り、都市計画の重点課題を郊外に置けたこと、(2)関東大震災、 函館大火の復興計画の経験、蓄䅡があったこと、(3内務省は欧米のパー クシステム、グリーンベルトの娚查研究を進めていたこと、(4)札幌では 邚外の丘陵、河川など地理的な条件に恵まれていたこと、などが考えら れる。

街路、風致地区が決定されてから数年後、1942 年(昭和 17 年) と 1943 年 (昭和 18 年) の 2 度に分けて、「将来の都市計画公園の運鎖」を実 現する札幌初の都市計画公園が決定された。1942 年に決定されたのは 美香保・白石・豊平の 3 公園であり、1943 年に決定されたのは琴似 ・ 伏筑の 2 公園である。 5 公園の面䅡は合計で約 $73 \mathrm{ha}$ であった。

\section{3、1942。43 年渗定都市計画公園の全体像}

都市計画決定の際に添付された「公園計画理由揞」39（図 1）では、 次のように現況を踏まえた上で公園配置計画の考えを述べている。

「....今、市内の公園配置を一算するに円山，中島及び大通の 3 市営公園 とその他公開緑地として植物園, 豊平館庭園等あり。何れも市民により 活用せられ、その配置また略々適当なりというべきも、市の近郊にして 嗃からずして市街化せんとする北部及び豊平川の東部を見るに一の公園 緑地施設の見るべきものなし。茲において都市計画広路 5 号線及び 7 号 の環状緑地帯に沿い、平戦両時の利用を考虑し、約 2 キロメートル間陆

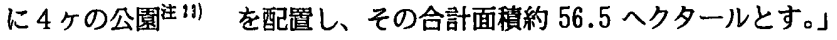
つまり半径 $3 \mathrm{~km}$ から $5 \mathrm{~km}$ 圈内に約 $2 \mathrm{~km}$ の間隔で均等に公園を配置する方 針が示されている。〈図5〉

この都市計画決定には、市街化が進行し、地価が高腾する前に公園緑 地を確保するという意図があった。「美香保公園計画理由書」40（図 6) には、次のように書かれている。

「…特に美香保公園予定地は既にその數地内に二、三人家を抱擁し、こ れをこのまま放任するにおいては遂に家屋密集し、地価高腃して息々実 施困難に陥るのところあり。ここにおいて将来運動公園を主眼とせる美 香保公園予定地の内地積約 6.612 ヘクタールを買収し、差当り支障物件 を移動除去し、運動公園として利用し得る最小限度の施設を行い、将来 時局の安定と市財政の許容する䉇囲において種々計画的施設の完成を期 せんとするものなり。」

さらに平時の保健慰楽という目的のほかに災害時の防災緑地という 役割も想定されていた。「豊平公園計画理由書」41〉には、公園の均等な 配置と利用の考え方に加えて次のような記述がある。

「従ってこれが完成の暁に於て札幌市は愈々その現代都市としての要素 を具備することとなり、名実とも北海道の首都としでの体裁を整うると 共に、従来この種の公園の均齊的利用に恵まれざりこの方面の市民 に二天恩恵を与うることとなるものにして、すなわち平素保健慰楽のた め用に供せらるるはもちろん、一朝非常采害の時に当たりては極めて必 要なる防空防火の保安緑地を得ることとなるものなり。」

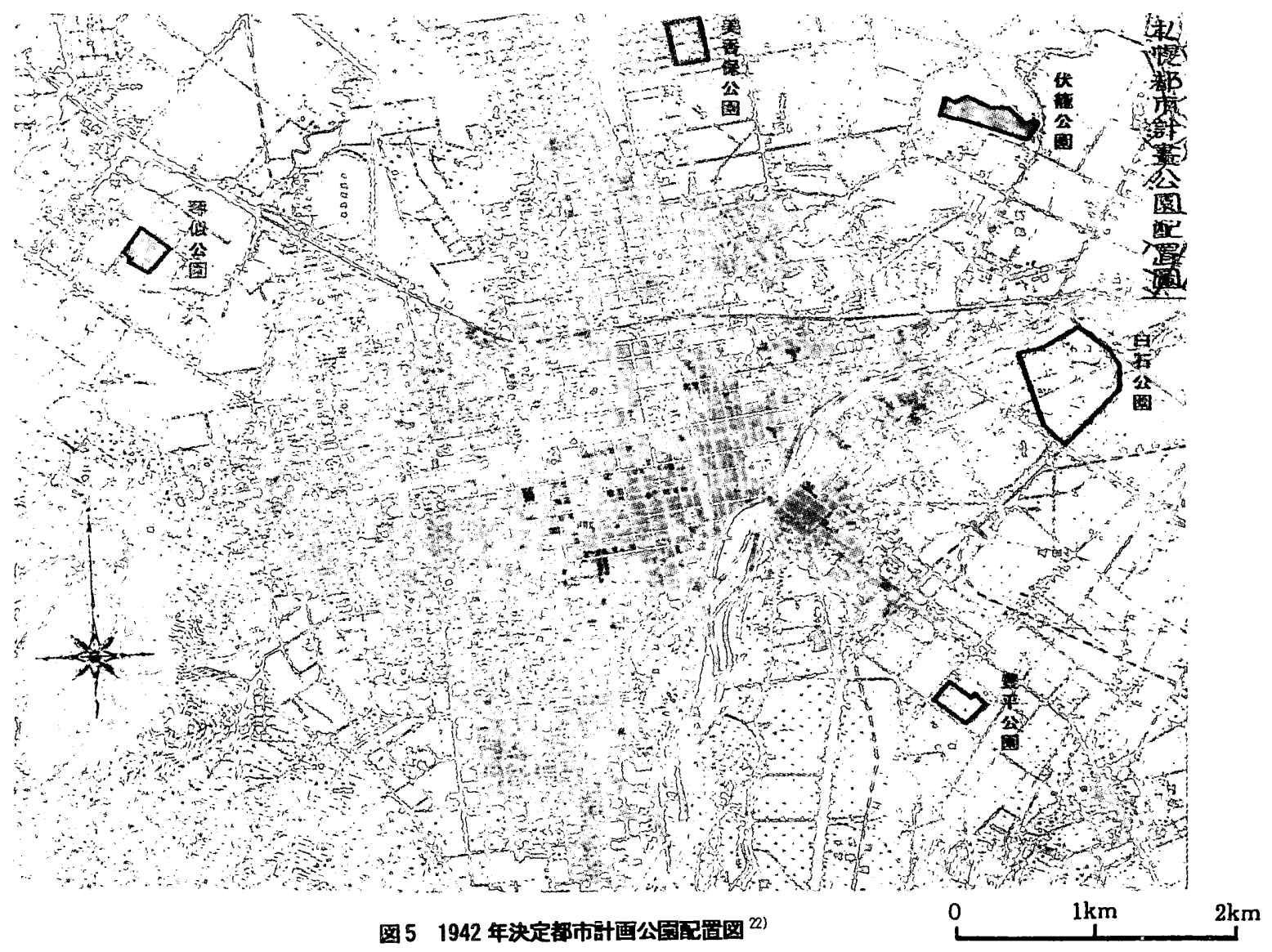

札视市所蔵。原図は 1:25000。右上の图名は原図の襄紙に記載されていたものを移動。 公園名と公圈区域は図面縮小により判読しにくくなったため、筆者が太字で加筆。 


\begin{tabular}{|c|c|c|c|c|c|c|c|c|c|}
\hline 7 & $\hat{\text { S }}$ & $\pi$ & 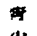 & 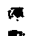 & 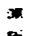 & + & $\overline{\bar{N}}$ & 4 & \\
\hline : & \pm & 4 & 4 & s & $x$ & 4 & & 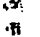 & \\
\hline$*$ & & क & + & $\dot{\nu}$ &. & & $=$ & $\because$ & \\
\hline & & ź, & 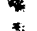 & $\dot{x}$ & 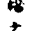 & 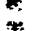 & 4 & $x$ & \\
\hline 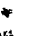 & 75 & 7 & $=\dot{n}$ & \#? & 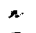 & $A$ & $=$ & 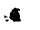 & \\
\hline & ; & $\therefore$ & $=$ & 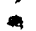 & ; & 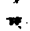 & 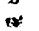 & $\pi$ & $\%$ \\
\hline • & & $=$ & * & $*$ & $\vec{z}$ & ه. & - & $\$ 6$ & $\Leftrightarrow$ \\
\hline$\because$ & $=$ & 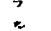 & 83 & $x$ & 2 & 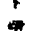 & 3 & + & 3 \\
\hline$z$ & $\varsigma$ & & $\therefore$ & 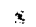 & $\#$ & \& & $=$ & $\Rightarrow$ & $\approx$ \\
\hline & 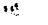 & & $n$ & + & + & f & $\mp$ & a & $\Rightarrow$ \\
\hline & 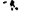 & & r & 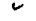 & $\therefore$ & ' & 7 & 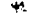 & 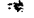 \\
\hline 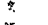 & 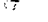 & & $\vec{*}$ & ${ }^{7}$ & 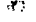 & 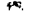 & $r$ & w: & $x:$ \\
\hline & rim & & $=$ & $=$ & 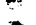 & $=$ & 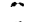 & 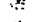 & $\pi$ \\
\hline 7 & F. & & $\therefore$ & 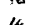 & N" & 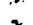 & ( & . & \\
\hline + & $\Rightarrow$ & & $a$ & $\because r$ & $\because$ & $\cdots$ & $\ldots$ & f. & \\
\hline$\because$ & 2 & & $=$ & + & $\Rightarrow$ & 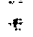 & 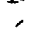 & $\because$ & \\
\hline
\end{tabular}

图 6 美香保公園計画理由書注24) 40) 札愰市所藏

平時に加えて、非常災害時における公園緑地の機能、役割を想定する ことは今日でも同様である（広域避難地、防災拠点など）。しかし、既 述の理由書注 9) 注 24)に加えて、以下で詳しく明かされるように、札幌の 都市計画公園の主目的は非常災害時よりも平時の保健慰楽に重点が置か れ、運動場、競技場、市民農園などが公園の主な内容であった。また公 園区域も必要な範囲に限定しており、面積も最大で約 40ha、多くが約 7〜10haの大きさにとどまっている。

同時期、1940〜1943 年、東京、大阪、名古屋、横浜などの大都市で は同じ内務省のグリーンベルト思想に基づきながらも、種別は緑地で、 面積は大規模（多くは面䅐 $80 \mathrm{ha}$ 以上）に都市計画決定されている注74)。 この相違点をもたらした原因、背景としては次の点が考えられる。 (1)東京、大阪、名古屋、横浜などでは 1940 年以前に都市計画公園が既 決定であり、その一部は整備されていた。それに加えて、1940 年代前 半新たに、既存の都市計画公園よりも外側の郊外に環状緑地帯（都市の 膨張を抑制するグリーンベルト）を実現する第 1 歩として、郊外の丘 陵地、低湿地などに広い面積で緑地を決定し、施設はあまり整備せず、 自然地形を生かした活用を想定している注25)。 (2)都市の規模、都市化の進展はかなりの格差がある。札幌は人口 20 万 人台で漸増している中規模の都市であった（表 $1 、$ 表 2 参照)。一方、 東京、大阪、名古屋、横浜などは大都市であり、名古屋、横浜もこの時 期に人口が百万を突破している(例えば横浜の人口は 1927 年は 53 万、 1939 年は 87 万、1942 年は 104 万と激增) ${ }^{43)}$ 。

\section{4、個々の公園計画の特政}

次に個々の公園の特色を論じる。美香保公園、豊平公園、琴似公園 は新市街地の公園としてほほ同様の性格を有している。白石公園と伏籠 公園はそれそれ地理条件や現況を生かした特徵が加わっている。

\section{1) 美香保公園}

美香保公園は、鉄道以北の市街に北海道帝国大学構内のグランドを 除くと運動場となる土地が無かったため計画された。当時、札幌は全国 有数の不健康都市注 24)であり、運動公園が切実に必要とされていた。「美 香保公園計画理由書」40) 注 ${ }^{24)}$ には「一年の約半分を寒気と積雪との内に 送る一般市民は、戸外生活を営むの気運極めて稀なるを以て……戸外運 動施設の必要を痛感する。とある。なお 5 箇所の公園の設計予想図に は陸上競技場や球技場に加えて、水泳場や角力場まで図示されたものも ある。
美香保公園の計画地は、大正期まで大半が牧草地であり、昭和 3 年 いったん宅地分銥されたが、人家はまだ少なかった。設計予想説明書 ${ }^{44)}$ によると東西約 $244 \mathrm{~m}$ 、南北約 $340 \mathrm{~m}$ 、面積 $8.278 \mathrm{ha}$ を有し、北部に約 $200 \mathrm{~m}^{2}$ の広場、南部には幼児や少年のための遊戯場を設け、周囲は風致 と風防を兼ね、幅 $10 \mathrm{~m}$ の緑樹帯を置く予定であった。

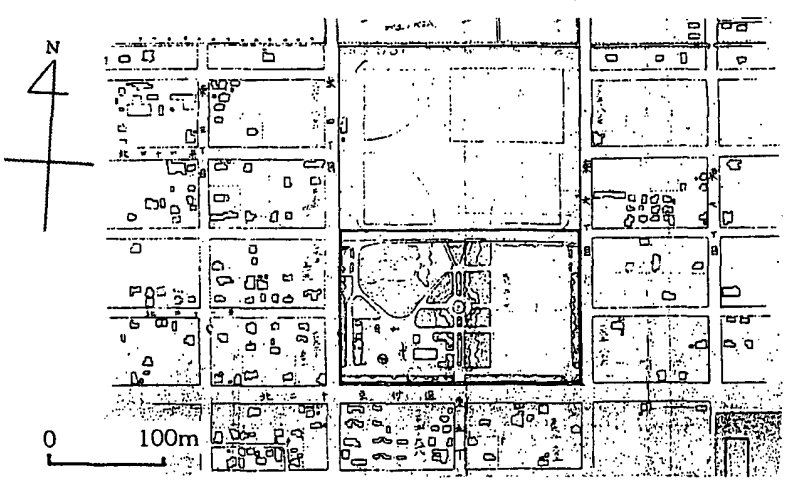

図 71942 年決定美香保公圈設計予想图 ${ }^{2)}$ 札煶市所藏 原図は縮尺 $1: 3000$

2）白石公園

5 公園の中で最大面積 $39.202 \mathrm{ha}$ の白石公園は、市街地東部の中心公 園となるよう豊平川と一体化して計画された。「白石公園付近地現況」 ${ }^{45}$ には「…現在国道 27 号に沿い、交通便利にして付近一帯工業的発展を 遂げん傾向にある中に保留されたる重要なる緑地なり」とある。

この付近は豊平川下風致地区に接し、良好な自然緑地が広がっていた か、周囲が鉄道や国道に囲まれるという交通の利便性から工業化の進展 が予測されたため、先行的に公園の確保を図ったのである。

この公園の特色としては、豊平川治いや公園外周部に食料確保のため の市民農園が大規模に計画されていたことが挙げられる。計画面積中約 23.8ha は運動公園として陸上競技場や球技場、体育館を設け、残りの 約 15.4ha は市民農園として一般に開放される計画であった。

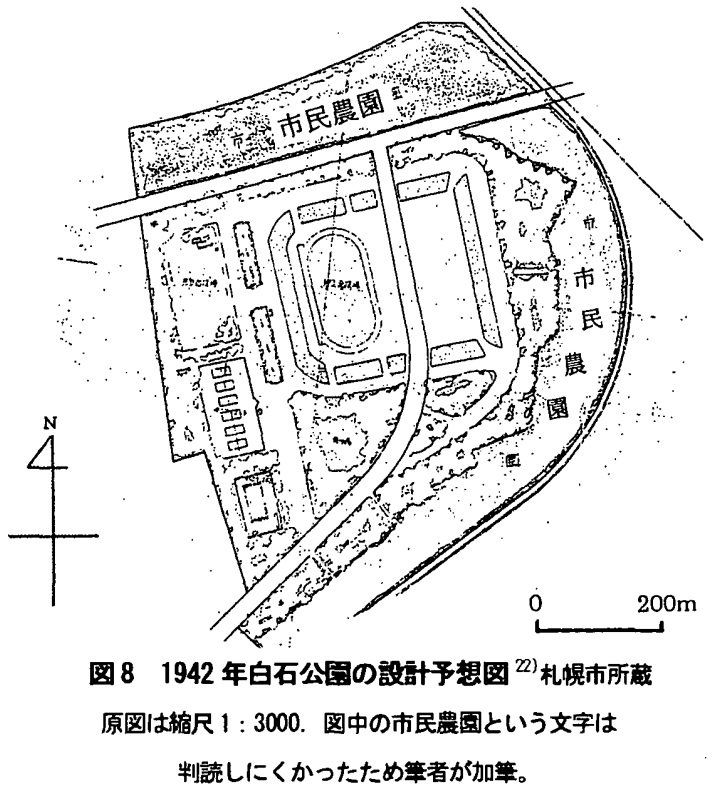

3）豊平公園

豊平公園は市街地東南部に位置し、広路 7 号白石平岸通に接し、計 画面積は $7.825 \mathrm{ha}$ であった。公園予定地は一部が田畑、大部分は果樹 園であり、人家は 1 戸のみであった。しかし近い将来に市街化の可能 
性があるものとして公園設置が計画されたのである。設計の内容は、陸 上喑技場、遊戯場等の他、1.1ha の逍遥園を配し、「休䓹公園としての 機能を具備」46) していた。

4) 琴似公園

琴似公園は市街地西部の新たな公園として計画され、面秋約 $6.7 \mathrm{ha}$ の土地で、住宅が 2 戸あるほか蘶蒸裁培地で、278 坪は国有圭開地であ つた。付近には農拿・工業の両試験場をはじめ時局産業に関する各種工 場があり、交通の便と良貿の飲㘰水に恵まれ，住宅地として発展を遂げ つつあった。公園の内容は他と同樣、䪭技場や遊戲場が計画された。

\section{5) 伏筑公園}

伏籠公園は市街地北賁部に計画され，屈曲した伏笵川をそのまま利用 して公園内に职り込み、豈かな自然地形を生かした公園であった注 26)。 さらに広路 5 号大学雁来通、広路 6 号伏籠公園通と一体となり、水と 緑の䅱かなオープンスペースとなることが目指されていたのである ${ }^{36) 。 ~}$

約 $11.4 \mathrm{ha}$ の公園予定地のうち 3 分の 1 か河川並びに堤防影地であり、 他は 5 戸の住宅を有する高煰肥沃な民有の畑地であった。また河畔に は芦が点茂し、堬や胡㭠などの木があり、川を隔てた対岸には札幌村第 一国民学校が位置していた ${ }^{48)}$ 。この公園は、面稳 $11.4 \mathrm{ha}$ の敨地に摆動 公園、児童游觑場、逍遥園を設置する予定であった。

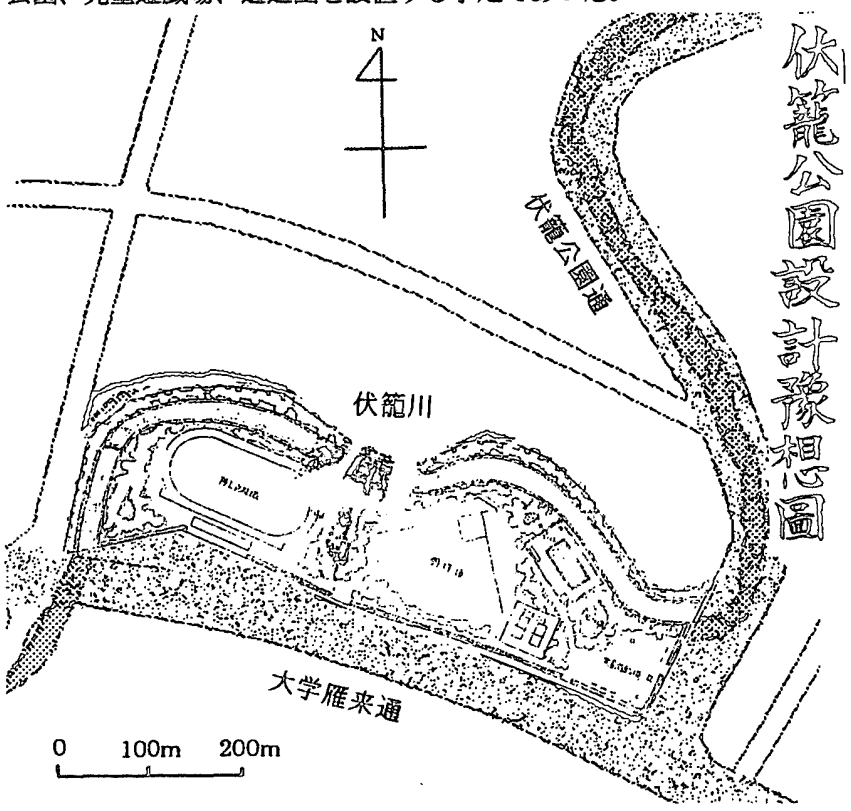

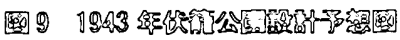

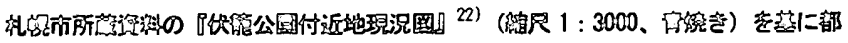

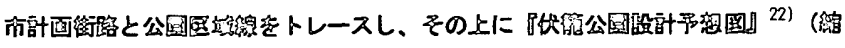

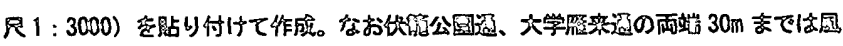

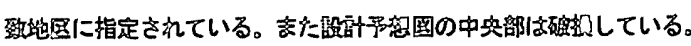

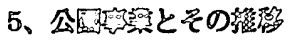

5 箇所の都市計画公園《 1942、43 年計画決定されると同時に何れも

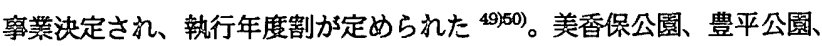
琴似公園、伏笵公園は札幌市長の施行とし、当時白石村に㩔していた白 石公園は北海道長官が施行するとされた。

しかし、それそれの公園は 1945 年（昭和 20 年）までに何れも用地 買呮は完了したものの、整地や施設は赤着手のまま終戦を迎える。その 中で唯一開設されたのは美昇保公園であった。
戦後、残り 4 箇所の都市計画公園の用站は、自作農創設地として国 に買叹された。これは全国の大都市と共通の現鉒であり、札幌も例外で はなかった ${ }^{4)}$ 。これが戦前決定の都市計画公園が計画どおり寒現され なかった一番大きな理由である。

その結累 5 つの都市計画公園は、下記のように大半が面䂓を縮小、 あるいは計画を廃止して現在に至っている。

- 美香保公園 $8.3 \mathrm{ha} \rightarrow$ 計画どおり開設

- 白石公園 $39.2 \mathrm{ha} \rightarrow 2.7 \mathrm{ha}$ (昭和 51 年)

・豊平公園 $7.8 \mathrm{ha} \rightarrow$ 廃 止 (昭和 35 年) 注 27$)$

。琴似公園 $6.7 \mathrm{ha} \rightarrow 2.0 \mathrm{ha}$ (昭和 41 年)

・伏簿公園 $11.4 \mathrm{ha} \rightarrow 6.6 \mathrm{ha}$ (昭和 46 年)

しかしその一方で札幌の郊外の新市街地では 1950 年代以降、小規模 な児童公園や近隆公園が整備されていった。

\section{6、缩露}

1942、43 年に決定された札幌の都市計画公園についてその特徵と意 義をまとめると次のようになる。

(1)札幌では用途地域 街路、風致地区に続いて公園の決定を行った。こ の都市計画公園は既存の公園と将来の公園配置を勘案して、新市街地を 環状に取り囲むよう、ほぼ均等に配賄された。つまり札幌の都市計画公 園は個々に決定されたものではなく、全市的な公園配置計画に基いてい る。な竦全市的な都市計画公園の決定は既に東京、名古屋、大阪などで 亲例があり、札幌が最初ではない。 (2)太幌の都市計画公園は都市計画街路、風致地区と密接な関係をもち、 一䢚の都市計画として決定されている。この三者を結ぶものはパークシ ステム、グリーンベルトの計画思想である。札幌では街路と公園という 最も基本的な都市施設が有烧的に計画され、の両者を風致地区が䇣い でいる。札幌の都市河川の多くは都市計画街路（広路）と風致地区に決 定されており、公園と河川も一体化した都市計画となっていた。札幌の 都市計画公園には公園、街路、河川を殿合して緑地空間を形成しようと する都市計画思想が見られる。

(3)全国の都市計画決定の案件は都市計画地方委員会の原案を経て、本省 （内務省都市計画䛺）が内容を指尊してふら、札幌の部市計画には内務 省の都市計画思想が反映されている。1930 年代、内强省では飯沼一省 (都市計画諰長)、北村徳太郎（公園主任技師）らが欧米の地方計画、 緑地計画を調㚗研究し、『都市公諭』『公園緑地』誌では多数の諭説や細

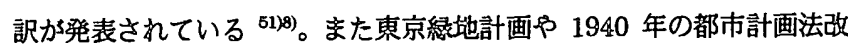
正を受けて 1940〜1943 年、曺京、大㟲、名古屋、横浜、川筒などで大 規模な緑地が都市計画決定された。化幌の都市計画公園も当時内强省が 推進した緑地計画の成果の一つである。

(4)同じ内務省の緑地計画の思想に基づき決定された公園緑地でありなが ら、札幌では比鞂的面䝿が小さな公園、他の大都市では面筫の大きな緑 地が決定されている。このような相邀点は都市の規模、公園緑乩に要請 される施設内容が背景となってかり、全国の中規模都市の中では札幌は グリーンベルト思想を忠実に実践した先進蚝例である。札幌で先進的な 都市計画を具体化できた背景には、既成市街地がインフラ整備済みであ り、新たな計画㹎題に职り組む拿を可能とする桑件を有していた。いい かえれば、都市計画の害験場としての条件が備わっていたためである。 (5)札瑺の都市計画公園の施設は主に戸外リクリエーションを想定してお 
り、軍事施設や防空施設は予定していない。1943 年東京、大阪では防 空法に基つく空地帯が指定されたが、札幌では指定されていない。札幌 の都市計画公園は平時の市民利用を主目的としており、この事は都市計 画決定や事業の説明書、設計予想図からも明らかである。

論文の最後に付言すると、札幌の都市計画公園事業化の推移、また都 市計画公園と関連していた都市計画街路と風致地区の戦後の状況など、 これらの課題については別の論文として研究発表を行う予定である。

札幌市環境局緑化推進部公園計画課、企画調整局計画部都市計面課の皆様 には保存文患閲覧等で大変、お世話になったことに謝意を表します。

\section{注颗}

注 1) 1923 年 5 月に人口 9 万以上の都市及ひ特に必要と認めた都市に都市計面法 の道用が抁大された。その 25 都市は次のとおり。札幌、小棬、画館、堺、尼崎、 新渴、豊橋、静岡、浜松、岐皁、仙台、金沢、岡山、広島、吳、下関、福岡、門 司、小倉、若松、八幡、大车田、熊本、長崎、鹿児島 ${ }^{1)}$ 。

注2）1933 年の都市計画法改正により町村まで都市計画が適用可能となり、1935 年に全国で 128 市、322 町村に適用され、1940年には全国で 177 市、451 町村に 適用された。1940 年現在の全国における都市計画決定の状況は、街路については 159 市、115 町村で決定さ似用途地域仗 93 市、5 町村で決定されているか、公 園の決定は 49 市、17 町村であった ${ }^{2)}$ 。

注3）1935 年現在、公園が都市計画決定されたのは全国で東京、横浜 名古屋、 大阪、函館、富山、岐皁、長野、長猗、鹿児島の 10 都市。このうち東京、横浜、 函館は災害復興計画の一環として決定されている 。

注 4) 両雑誌共に内務省都市計画課か実質的な編集を担当している。

注 5）代表的な詥考を挙げると、北村徳太郎 : 都市の緑地問題、都市公馀、13 巻 1 号、1930 年、北村德太郎 : 地方計画を通しての緑地計画、都市公諭 17 巻 1 号、 1934 年、内務省: 時局と緑地計画、公園緑地、4 巻3 号、1940年。

注 6)『東京緑地計画概要』(東京府、1938 年)にはボストン広域パークシステム (1902 年) が東京緑地計面と比較して図示されている。また、訟園緑地』東京 緑地計画特輯号（1939 年 3 月）では「世界都市緑地計面比較図」として 9 都市、 東京緑地計画、新京、ワシントン、ニューヨーク、シカコ、ロンドン、ウィーン、 パリ、ベルリンの「公園系統図、「緑地計画図」が図示され、解説されている。 注 7) 『公園緑地』誌に揭載された東京、大阪、名古屋、横浜、川崎に関する詥考 の例は次のとおり（揭载誌の発行年月を記す）。1939 年 3 月の東京緑地計画特集、 1939 年 12 月の大阪特集、1940 年 4 月の東京大緑地特集、1940年 9 月の满州特 集、1940 年 11 月の名古屋大緑地計面、1941 年 3 月の横浜大緑地計画、川崎に於 ける大緑地造成、1941 年 10 月の大阪府に於ける大緑地設定に就いて、1942 年 2 月の続東京緑地計画特集、1942 年 9 月の大阪都市計画事業緑地計画とその運営、 名古屋都市計画緑地事栗概況、川猗市の緑地事桠。

注 8 ）都市計画地方委員会は、大正 8 年 11 月 27 日栜令第 483 号「都市計画委員 会官制」によって設置されたもので、内務大臣の監督に属する内稀省の出先機関

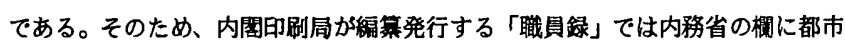
計画地方委員会が記載されている。

注 9）本文書の記载内容は以下の通りである。傍点は引用者か加えた。

「札幌市都市計画公園計面及事業決定二関スル件

都市計面公園琴似及伏籠二対スル計田並二事業決定資料左案二依り夫々提出相成 可哉 案 札土都第 8 号 昭和 18 年 2 月 市長」

「一、公園計面理由書
札幌市八本道文教政治ノ中心地ニシテ規矩整然且広闊ナル街路之二配スルニ䇣茂 セル樹木、広䭗ナル緑地卜清洌ナル豊平川、創成川並二仗籠川等ノ水流アリ又畏 二八都市計画街路地域及風致地区並美香保、豊平、白石ノ 3 公園等ノ決定セラル ルアリテ都市計画トシテハ稍完備セルノ感ナキニアラザルモ市势ノ目覚シキ伸展 八計面区域内包容人口トシテ予想スル 50 万都市実現モ遠キニ非スト推察セラルル

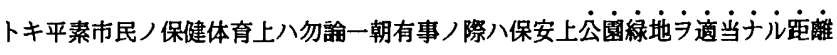
配置スルコトハ極メテ必要ナルノミナラス現下国土防衛ノ見地ヨリモ之ヨ他ノ既 成都市ノ実情二篮ミ忽二為シ得サルモノアリ旁今市内公園及是二準スルモノノ配 置ヨー筸スル二円山、中島、山鼻及大通ノ市営公園ノ外植物園」〈左〉

注 10）札幌区役所編『札幌区史』1973 年、782 頁には次のような記述がある。「... 明治 4 年岩村判官西村権監事等の再経営に於ては、札幌本府の䑤地をさらに北方 東創成通西 4 丁目南角に相して建策し、同年札幌市街の区画を定むるや、該廳を 中心として方 1 里の地を以て市街と定め…」」

注 11）資料として宮地常助 ${ }^{24)}$ 、『札幌都市計画』 ${ }^{26)}$ 『新札帨市史 第 2 巻通史 2 』

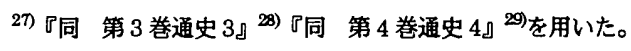

注 12）札幌市教育委員会編『新札幌市史 第 3 巻通史 3 』1994、117-119 頁によ ると明治 43 年 4 月 1 日、机幌村の南西部、白石村字上白石村、豊平町豊平村の札 沅区に接続する地域と藻岩村大字山鼻村の元屯田兵村ほほ全域を札幌区に編入す る一方、札璂区内であった現在の北 26 条以北の地域が琴似村へ編入された。

注 13）1871 年〈明治 4 年〉開設。現在の大通公总。

注 14）1887 年（明治 20 年）開設。

注 15）1903 年（明治 36 年）公園予定地として払下げを受ける。

注 16）札幌で最初にできた公園”偕楽園”（1871 年開設）は中島公園の開設に伴 い衰退して、1897年〈明治 30 年〉当時の実力者対馬贺三郎に払い下げられた。

注 17）なおその当時の状況に関しては札幌市教育委員会編『机帨歴史地図〈明治 編〉』 ${ }^{30)}$ 『同〈大正編〉』 ${ }^{31}$ 『同〈昭和編〉』 32 に図面がある。

注 18）これは当時の市域 $2417 \mathrm{ha}$ の約 4.3 倍に当たる。

注 19）この他に、都市計画街路の変更、圆山町の編入に伴う都市計画区域と用途 地域の変更が存在するか、、省略する。

注 20）日本におけるパークウェイ、フールヴァールの全体像については、参考文 献 34)、35)を参照。

注 21）引用に際しては、原文の旧漢字やカタカナを新漢字、ひらがなに適宜改め、 句読点を加えた。また傍点は引用者加加えた。以下同梯。

注 22)1932 1937 年、兵庫県西宮市では市内の主要河川である凬川を都市計画事 業により全面的に公園化している。これは河川を都市計画街路(遊歩道と植樹带か らなる街路）に決定して公園をつくるという先進的で特異な都市計画であった ${ }^{38)}$ 。 注 23)この「4 ケの公園」は伏籠公園が 1943 年(昭和 18 年)の決定となったため「3 公園」に変更になり、1943 年の琴似、伏籠の 2 公園と合わせて最終的には $73.4 \mathrm{ha}$ が計画された。

注 24）内容の一部は次の通りである。傍点は引用者が加えた。

「美香保公園計画理由毒

札幌市八北海道ノ首都トシテ従来都市計面上必要ナル各種施設ノ整備充実二留意 シ来リシカ保健施設ニ至リテハ将来一般ノ努力ヨ要スルモノアリ即チー年ノ約半 分ヨ寒気卜糟雪卜ノ内二送ル一般市民八戸外生活习営ムノ気運極メテ稀ナルラ以 テ之レカ糟極的対策トシテ温暖地方ノ諸都市同様户外運動施設; 必要户痛感スル 処ナレトモ現在適当ナル公園ヨ有セサルカ為メ青少年ト踓屋内二䖝居ヨ余僮ナク セラレ為メニ稍モスレ八全国有数；市健康都市ノ名サへ冠セラル今ヤ長期建設下 国ヨ・ケテ国民体位向上二努カシッッアリ特二体筫八年々著シキ低下ヨ示シ之レ

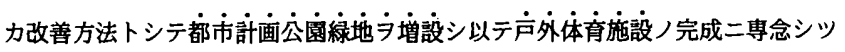


ッアルノ時一度札蝭市力所有スル公」

注 25）大阪府の大緑地では馬事訓練場、芝生（大教練埸）、厚生運動施設、船艇修 練施設なとを予定したが、右施設は各緑地の天然の地形、地物を出来る限り利 用」との方針で、しかも、「広大なる土地が将来大阪府民の自由空地として公有に 恠し、公共の用途を発搼することを想へは、士地獲得の成功するのみを以て大半 其の目的を達し得たる」42)と明確に述へでり、軍事的、防空的な色彩は実際には ほとんと存在せす゚、また、高射砲陣地なとは設罚されていない。これは果京、横浜、 川倚、名古屋でも同様であり、大緑地を何に使用するか県庁各課から要望を提出 させている注7)。

注 26）伏篰川は古い札沅川という意味で、かってはその名のととおり、豊平川本

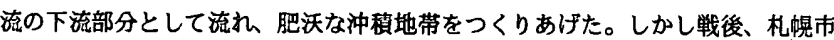
の人口增加に伴い、污染が激しくなり、直線状に改修され、さらに埋め立てられ た ${ }^{47)}$ 。

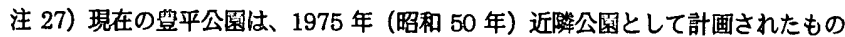
である。面䅡は 7.4ha であるが、1942 年の計画とは異なる場所にあるため別の公 疄と考えて良い。

\section{考嚆}

1)都市計画協会編『近代日本都市計画年表』都市計画協会、1991。

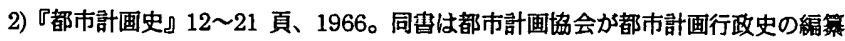
学備のために取りまとめた刊行物、建設省の元幹部職員が執笋。 3)越澤明 : 公图緑地計画の展開と近代日本都市計面、都市計面、176 号、18-23、 1992 。

4)佐藤昌『日本公图緑地発達史』都市計面研究所、1977。 5)石川幹子 : ボストンにおける公固緑地系統の成立に関する研究、造圆雑誌、54(5)、 84-89、1991。石川幹子 : ボストンにおける広域パークシステムの成立に関する歴 史的研究 都市計画論文集、28 号、565-570、1993。石川幹子：ミネアポリスに おける公图緑地系統の成立に関する研究、造囷雓誌、56(5)、43-48、1993。石川 幹子 : ロンドンのグリーン・ベルト計画思湖の変逻に関する歴史的研究 都市計 画詥文集、29 号、331-336。

6)佐藤昌『日本の公总緑地 120 年の歩み』日本公園緑地協会、1993。

7)日本公圈緑地協会編『日本公图百年史日日本公图緑地協会、1978。

8)北村德太郎先生生誕百年記念事業実行委員会編『北村徳太郎公图緑地論集』日 本公图緑地協会、1995。

9)木村英夫：内務省時代の都市計画の回想一本省、都市計画、144、1986。 10)木村英夫『都市防空と緑地・空地』日本公圈緑地協会、1990。

11)前島康彦『東京公总史話』東京都公图協会、1989。

12)末松四郎『東京の公圈通誌』東京都公图協会、1981。

13)越淬明『東京の都市計画』岩波雪店、1991。

14)越澤明 : 名古屋の都市計画の成り立ち、アーバン・アトハバン、6 号、133-141、 1995。

15)名古屋市計面局、名古屋都市センター編『名古屋市都市計画史 (大正 8 年 昭 和 44 年)』名古屋都市センター、91-99、163-174、1999。

16)向口武志：『名古屋都市計䧃公圈』の計画理念、日本建築学会計䧃系椧文集、522

号、207-214、1999。

17)越淖明：大阪の公图緑地計画の推移、公固緑地、51(2)、86-94、1990。 18)札愰市史編集委自会『札幌市史政治·行政編』札幌市、349-358 頁、1953。 19)枕䇎市教育委員会編『新札幌市史 第 4 巻通史 4 』札幌市、314 318 頁、1997。 このうち都市計画決定に関する記述は 315-316 頁のみであり、全体図、個々の公图
緑地の図面は収録されていない。

20)札靦市教育委員会編『さっぼ万文庫 64 公園と緑地』著作権者札垷市、発行北 海道新間社、208-211 頁、1993。大金善三郎（札幌市公固緑化協会常務理事）執 笋の同頁には白石、豊平、伏籠の三公園の設計予想図が収録されているか、記述 はきわめて簡単であり、都市計面決定の全体状況に関する記述は無い。 21)都市計面北海道地方委員会『都市計画北海道地方委員会議事速記録』。1929 年 5 月の第 5 回 1937 年 10 年の第 15 回の各冊。

22)札婗市役所保存文䡒『札埧都市計画公園計画及事業決定二関スル件』経り。こ の保存文害は厚さで約 $80 \mathrm{~cm}$ となる保存文曹経りの総称。

23）『都市公諭』2O(7)、北海道特輯号、1937。 24)宮地常助：札幌の風致地区、公園緑地、3(1)、18-24、1939。 25)札幌市建設部計画課『札帨都市計图概要』札幌市 1954 。 26)札幌市建設部計画課『札幌都市計面』札幌市、1960。 27)机幌市教育委員会編 『新札幌市史 第 2 巻通史 2 札幌市、1991。 28）札幌市教育委員会編 『新机幌市史 第 3 巻通史 3 』札幌市、1994。 29）札璂市教育委貝会絆『新札幌市史 第 4 巻通史 4 』札幌市、1997。 30）札帨市教育委員会編『札幌歴史地図〈明治編〉』札幌市、1978。

31）札幌市教育委員会編『札帕慰史地図〈大正編〉』札幌市、1980。

32）札幌市教育委員会編『札幌歷史地図〈昭和編〉』北海道新聞社、1981。 33)都市計画北海道地方委員会 : 札幌都市計画区域設定参考資料 1926 。 34)越澤明 : 日本における広幅目街路とフールバールの計面・設計思想史、中村良 夫・筷原修・越澤明・天野光一『文化遺産としての街路』国際交通安全学会、1257 頁、1989。

35)越澤明 : 都市計画における並木道と街路樹の思想、国際交通安全学会、22(1)、 13-23、1996。

36)越澤明 : 札幌における 1936 年決定広幅貝街路の計画思想、土木史研究 19 号、 9-20、1999。

37）岩沢周一：京都風致地区指定と其の後、公園緑地、1(6)、12-22、1937。

38）越澤明 : パークウェイとして整俑された夙川公園の特數とその意㢳、国際交 通安全学会誌、23(1)、60-69、1997。

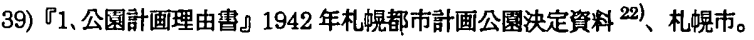

40）渼香保公囷計画理由害』1942 年札幌都市計西公園决定資料 ${ }^{22}$ ，札幌市。図 6 参照。

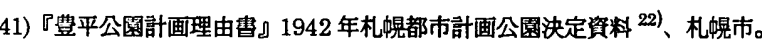

42）井本政信 : 大阪都市計画事業緑地計画とその運営、公園緑地、6(8)、11-13、 1942 。

43）横浜市建設局計面課：港都建設計画概要、1959。

44）『3、設椐予想説明曺』1、美香保公園より拔䊉、1942 年札幌都市計画公園決定 資料 ${ }^{22)}$ 、札幌市。

45)『2、現況説明書』2、白石公園付近地現況の口、環境概要より抜䊉、1942 年札 幌都市計画公圈決定資料 ${ }^{22)}$ 、机幌市。

46）『3、設計予想説明書』1、豊平公園より拔䊉、1942 年机煶都市計画公腮決定資 料 22)、札幌市。

47)机幌東区役所総務部総務課『東区今昔囚 1979 。

48）『2、現況説明宙』2、代籠公園付近地現況の口、環境概要より拔䊉、1943 年札

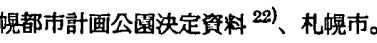

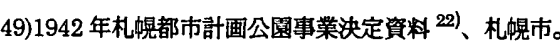

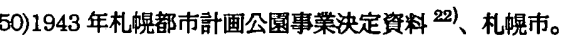
51)敛沼一省先生業䋶録編集委員会編『飯沼一省』都市計画協会、1989。 